han skrevet en bok som nok først og fremst er beregnet på personer som ikke har mye kunnskap om feltet fra før. Forfatterens innfallsvinkel er preget av hans lange yrkesliv som kliniker og rådgiver overfor barn med astma og deres foreldre. Han ønsker å formidle viktig kunnskap om kroppens reaksjoner samtidig som han gir praktiske råd om hva man kan gjøre for å bedre forholdene i barns innemiljøer for at de skal bli mindre belastet med uheldige påvirkninger. Bokens fortrinn er at Kjell Aas ser dette komplekse feltet fra pasientenes side.

Forfatteren går grundig til verks. Innledningen er en generell og leservennlig gjennomgang av en del begreper og temaer, som hvorfor inneklimaet er viktig, kroppens interaksjoner med de kjemiske stoffene vi kan eksponeres for, belastninger og tålegrenser samt overfølsomhet og allergi. Videre omtaler han begreper som miljøintoleranse og miljøhemning, som i stor grad er subjektive tilstander der entydige medisinske diagnoser ikke er mulig å stille. Dette omtales på en ryddig måte. Hvordan man skal håndtere denne type symptomer er nok omstridt i fagmiljøene, men forfatterens synspunkter er et nyttig innspill til hvordan man kan se på slike tilstander. En liten innvending er at denne delen blir noe omfattende før man kommer videre til selve inneklimaproblematikken. På den annen side angir forfatteren at boken ikke behøver å leses fra perm til perm, men at man heller leser de temaene man interesser seg mest for.

Videre omtales de vanligste inneklimaforhold, bl.a. fukt, muggsopp og partikkelforurensning, som for en del kan forårsake helseplager eller nedsatt trivsel, og hvilke tiltak man kan gjøre for å bedre inneklimaet. Det siste inkluderer såkalt kvalifisert skjønn, en metode forfatteren har utviklet for å kunne med relativt enkle midler vurdere inneklimaforhold på et gitt sted. Videre inneholder boken råd om bl.a. rengjøring, ventilasjon, bruk av luftrensere og ev. nytte av inneklimamålinger, vedlikehold, oppussing og nyanskaffelser. Samlet sett synes jeg temaene er behandlet på en grundig og lettlest måte. Boken kan derfor anbefales til dem som vil ha en innføring i inneklimaproblematikk og mulige løsninger.

\section{Rune Becher}

Nasjonalt folkehelseinstitutt

\section{På lag med sykdommen}

Seljeskog T.

Å leve med akutt intermitterende porfyri

En personlig beretning. 91 s, ill. Levanger:

Tove Seljeskog, 2009

Pris NOK 250 + porto NOK 30

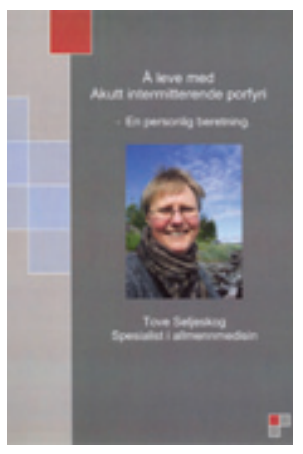

Forfatteren er 44 år allmennpraktiker i Levanger og tobarnsmor. Fra hun var tenåring fikk hun hodepine og tiltakende plager med magen. Først da hun var 36 år fikk hun diagnosen akutt intermitterende porfyri (AIP). Moren har samme sykdom.

Porfyriene er sjeldne. Det er kanskje 300 pasienter i Norge. De er autosomalt dominant arvelige og forekommer i seks forskjellige former i Norge, avhengig av hvilket enzym i produksjonskjeden for hem som er rammet. Kvinner har mer plager enn menn, fordi symptomene er delvis hormonavhengige. Symptomene kommer i anfall. Når sykdommen er så sjelden og så variabel, er det ikke mange leger som er oppdatert på den.

Det er en vanskelig kunst å skrive en bok «om meg selv og sykdommen min». Den må være personlig og detaljert, og det er vanskelig å passe grensene. Den må ikke bli så personlig at den krysser grensen til det private, og den må heller ikke virke selvopptatt og selvsentrert.

Forfatteren kommer nok nær disse grensene, men jeg synes hun klarer den balansekunsten. Viktige hjelpemidler er humor og nydelige naturfotografier. Hun har to viktige budskap. Det ene er å formidle kunnskap om denne sjeldne sykdommen som de fleste leger aldri ser. Det andre er å forklare sine egne mestringsstrategier. Det nytter ikke å kjempe mot sykdommen. Det bare erter den opp og forverrer plagene, fordi stress utløser anfall. Derfor må hun forstå sykdommen sin og spille på lag med den. Hun minner meg nesten om Alexander Kielland som sa: «Jeg oppfatter mine sykdommer som vennlige losjerende!» Porfyri er ikke akkurat vennlig, men den kan ikke nedkjempes. Derfor må den mestres, og hun klarer tydeligvis å være alt: sykdomsbærer, allmennpraktiker (riktignok redusert jobb), mor, husmor og forfatter - imponerende!

Hun skriver godt og gir praktiske råd ned til de minste detaljer. Poenget er nettopp at man hele tiden må være litt foran sykdommen, forebygge anfall og samtidig kunne håndtere dem når de kommer. Perfeksjonistene klarer seg bedre med denne sykdommen enn slappfiskene. Hvem bør så lese denne boken? Pasienter med akutt intermitterende porfyri bør selvfølgelig gjøre det, og det bør også leger som har slike pasienter. Her kan kanskje mange leger lære noe om holdninger til kronisk syke pasienter.

Peter F. Hjort

Blommenholm

\section{Ode til den offentlige hest}

Olsen SM.

Hestekrefter i offentlig tjeneste

462 s, ill. Oslo: Tun forlag, 2008. Pris NOK 549

ISBN 978-82-529-3209-6

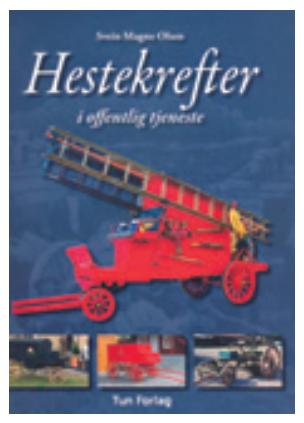

Det moderne Norge tok stort sett form i hundreårsperioden 1850-1950. Det meste vi har av infrastruktur kom på plass da. Det er derfor interessant at denne storstilte oppbyggingsperioden også faller innenfor den tiden

da hesten var den selvfølgelige arbeidskamerat. Hestens trekkraft dimensjonerte svært mye, fra landverts transporttider til gjennomførbarheten for større anlegg. Selv om mange hesteredskaper hadde tradisjoner langt bakover i historien, ble det også konstruert nye som var tilpasset nye innsatsområder, f.eks. veiskraper og pudrettvogner - eller den sledegående bussen fra Trondheim. Det meste av dette er for lengst ute av bruk, mye er borte og glemt nå, men det er likevel en viktig del av vår kulturarv.

Svein Magne Olsen har lagt ned et stort arbeid for å dokumentere hesteredskaper, og dette er en av hans bøker om dette. Her reiser han et monument over hesten i offentlig tjeneste, den navnløse forutsetningen for utviklingen gjennom en lang periode. Han har tatt for seg de ulike samfunnsfeltene, brannvern, forsvar, jernbane, post, telekommunikasjon osv. Helse har f.eks. fått et meget velskrevet 40 siders kapittel.

Det er ofte en svakhet ved historiefremstillinger av enkeltfelt at sammenhengen med konteksten blir for utydelig. Her er det snarere omvendt. Ofte er konteksten så fyldig og leseverdig at hesten trer i bakgrunnen - den ser bare traust på oss fra bildene. Forfatteren har kombinert det å skrive god historie med å lage en tiltalende bok som mange sikkert gjerne lar ligge fremme.

Illustrasjonsmaterialet er meget godt. Fotografier og kunstreproduksjoner er delikat gjengitt, og bokutstyret for øvrig er tilsvarende.

Dette må være den ideelle gavebok ikke bare til dem som er glad i hester, men 
til alle som synes norsk historie er spennende.

\section{Øivind Larsen}

Institutt for allmenn- og samfunnsmedisin Universitetet i Oslo

\section{Selvutvikling og tilheling gjennom kreativitet}

Berg-Frykholm A

\section{Självbilder}

215 s, ill. Uppsala: Bokförlaget Bergsäker, 2008 Pris SEK 350

ISBN 978-91-633-2659-2

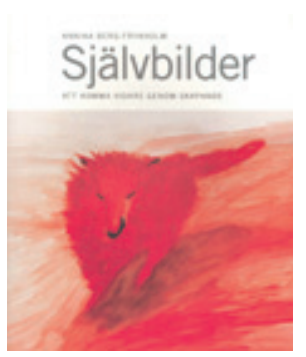

Overordnet målgruppe er alle med interesse for terapeutiske prosesser $i$ et menneskes liv. Boken kan derfor leses fra både et faglig og/eller personlig ståsted. Forfatteren er journa-

list med egen erfaring fra bildeterapi.

Utgangspunktet er en rekke intervjuer med personer av ulik fagbakgrunn, men med det til felles at de bruker bilder i sitt arbeid med lidende mennesker. Langt de fleste av de intervjuede har formell utdanning i bildeterapi. Hver av intervjuobjektene presenterer terapihistorier i ord og bilder. Fokus er på hvordan samspillet mellom bildet, pasienten og terapeuten kan utvikles og til sist gi lindring og skape selvinnsikt.

De lidende er i et vidt spektrum; barn med atferdsvansker, flyktninger, rusavhengige, voksne med psykisk eller somatisk sykdom, døende. Mot slutten omtales utdanning, visjoner og forskning innen bildeterapi - spørsmål rettet til lærekrefter ved ulike utdanningssteder innen bildeterapi i Sverige. Journalistens undersøkende, nyfikne blikk er tydelig - fordypet av forfatterens personlige kjennskap til bildeterapi. Ikke minst utgjøres boken av de mange lidendes vilje til å dele egne historier og bilder. Den er lettlest og rikt illustrert, bildene bevegende og av god kvalitet. Forsiden har en innbydende layout, med en tittel som vekker interesse. Boken er først og fremst skrevet med en stor respekt for hvilke iboende muligheter for endring som finnes i mennesket - og som slipper til gjennom det skapende. Det er ingen lærebok i bildeterapi, selv om det i teksten finnes gjemt «godbiter» som viser hvordan man kan arbeide med bilder. Forfatteren uttrykker i forordet et ønske om å gjøre bildeterapi lettfattelig og kunne spre kunnskap om metodens sprengkraft og uendelige muligheter. I tillegg gir den også en oversikt over fagmiljøets visjoner og status i forhold til forskning innen bildeterapi i Sverige.
Dette er forhold tett opp mot våre egne her i Norge. Boken anbefales i forhold til målgruppe og intensjon.

\section{Kari Rød}

Poliklinikk for spiseforstyrrelser Oslo universitetssykehus, Aker

\section{God dansk bok om thoraxkirurgi}

Hjortdal VE, Paulsen PK, red. Thoraxkirurgi

2. utg. 328 s, tab, ill. København: FADL's forlag, 2008. Pris DKK 625

ISBN 978-87-7749-477-2

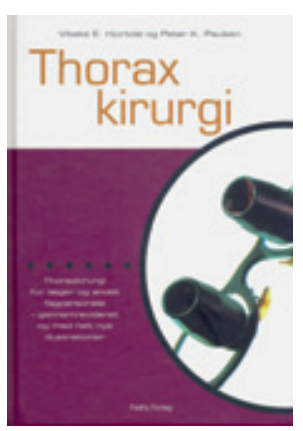

Målgruppen er studenter på slutten av studiet, yngre sykehusleger og praktiserende leger. Andre med interesse for faget vil ha god nytte og glede av boken. Den dekker hele fagfeltet: trachea lunger, brystvegg, oesophagus, torakalaorta og hjertet inklusive medfødte hjertefeil. Hjerte- og lungetransplantasjoner omtales også. På 328 sider er det ikke mulig å dekke alt dette med stor dybde, men man får en fin innføring og oversikt som mange vil ha nytte av. Gitt målgruppene er det helt greit at operasjonsmetoder og teknikker ikke er beskrevet.

Bak 20 kapitler, i innbundet og hendig format, står 38 danske kolleger som forfattere. De enkelte kapitlene er skrevet av sterke fagfolk. Det er en liten ulempe at betegnelser da kan variere. Etter nesten alle kapitlene er det litteraturliste for videre lesing og fordyping. Et godt stikkordregister, mange gode illustrasjoner og bilder og noen tabeller er alle med på å lette lesingen og å gi oversikt.

Forfatterne og utgiver skal ha ros for å lage og fornye en slik bok på et nordisk språk, og dansk er lett å lese. En litt plump vittighet, at thoraxkirurgi ble benyttet allerede $\mathrm{i}$ Edens hage da Vårherre brukte et ribbein fra den første mann for å lage den første kvinne, er ikke til hinder for å gi en sterk anbefaling av boken.

\section{Steinar Solberg}

Thoraxkirurgisk avdeling

Oslo universitetssykehus, Rikshospitalet

\section{For langsom fremgang i kampen mot malaria}

Verdens helseorganisasjon World malaria report 2008

210 s, tab, ill. Genève: WHO, 2008. Pris CHF 30 ISBN 978-92-4-156369-7

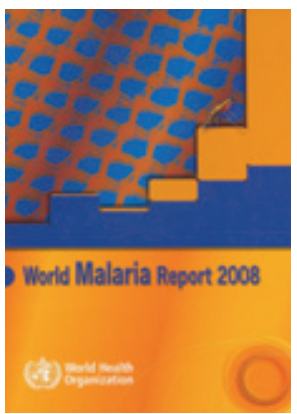

World malaria report utgis av WHOs globale malariaprogram og ble første gang utgitt i 2005. Målsetningen er å støtte utviklingen av effektive nasjonale malariakontrollprogrammer. Rapporten tar for seg utviklingen innen fem områder: sykdomsforekomst og trender, nasjonal malariapolitikk, implementering av kontrolltiltak, finansiering og effekt av tiltakene på malariaepidemiologi.

De innledende kapitlene omhandler forskjellige sider ved malariaepidemiologi og kontrolltiltak. Deretter følger en grundig beskrivelse av situasjonen i 30 høyendemiske land. Som vedlegg finnes en mer inngående forklaring på grunnlaget for estimatene og detaljerte tabeller over forekomst, intervensjonstiltak og finansiering i malariaendemiske land.

Det epidemiologiske datagrunnlaget er dels rutineovervåking og dels husholdsundersøkelser. Usikkerhet i estimatene og mulige feilkilder diskuteres grundig. Med dette forbehold hevdes det at halve verdens befolkning (3,3 milliarder) lever i endemisk område. I 2006 beregnes det å ha vært 247 millioner tilfeller av malaria, hvorav $86 \%$ i Afrika, og nesten en million malariadødsfall. Falciparummalaria utgjorde $91 \%$ av alle tilfellene. De fleste dødsfall var blant afrikanske barn under fem år.

I 2005 satte Verdens helseforsamling som mål at innen 2010 skulle minst $80 \%$ av verdens befolkning ha tilgang på fire viktige virkemidler mot malaria: insektsnett impregnert med insekticider, effektiv malariabehandling (artemisin i kombinasjonsbehandling), insekticider til innendørsbruk og forebyggende behandling i svangerskapet. Det ble også satt som mål at morbiditet og mortalitet som følge av malaria skulle reduseres med minst $50 \%$ innen 2010 og $75 \%$ innen 2015. Rapporten peker på at selv om bruken av WHOs foreslåtte virkemidler har økt, er målene fra 2005 langt fra nådd i de fleste land. Likevel har den estimerte malariainsidensen vært fallende noen steder, sannsynligvis dels som følge av de implementerte tiltakene.

WHO sikter ikke bare mot å redusere forekomsten av malaria i endemiske land, men har også som mål å begrense den geografiske utbredelsen av sykdommen og 